\title{
Coastal Regional Sediment Management Planning In Southern Monterey Bay, California
}

\author{
David S. Brew, Philip Williams \& Associates, 550 Kearny Street, Suite 900, San Francisco, CA 94108, \\ USA'., d.brew@royalhaskoning.com \\ Robert T. Battalio, Philip Williams \& Associates, 550 Kearny Street, Suite 900, San Francisco, CA 94108, \\ USA., b.battalio@pwa-Itd.com \\ Edward B. Thornton, Naval Postgraduate School, 327 Spanagel Hall, Monterey, CA 93943, USA., \\ thornton@nps.edu \\ Clifton Davenport, California Geological Survey, 135 Ridgway, Santa Rosa, CA 95401, USA., \\ clif.davenport@conservation.ca.gov \\ Brad Damitz, Monterey Bay National Marine Sanctuary, 299 Foam Street, Monterey, CA 93940, USA., \\ brad.damitz@noaa.gov
}

\begin{abstract}
The coastal dunes and beaches of southern Monterey Bay (the Bay) are eroding at approximately four feet per year, placing oceanfront property, infrastructure, and natural habitat at risk of loss. Erosion is exacerbated by mining operations that extract sand from the beach near the City of Marina. Recognising that much of California's coastal erosion, sediment supply and demand issues can be attributed to human modification of natural processes at regional scales, Regional Sediment Management (RSM) is being pursued by the responsible agencies. This paper presents the findings of the Coastal RSM Plan developed to address erosion in the Bay. The Plan first evaluates the sedimentary processes, erosion rates and sensitive species and habitat along the coast. Those data sets are then combined with economic, ecological, and societal considerations, to identify critical areas of erosion and to propose RSM-based solutions. The Plan recommends three main RSM strategies for the Bay. (1) reduce or eliminate mining of sand from the beach at Marina. Sand mining creates a sediment sink which increases erosion potential and, if stopped, erosion rates would slow. (2) allow dune erosion to continue without human intervention along the undeveloped sections of the Bay. This erosion would continue to supply large volumes of sand to the beaches, providing benefits for sensitive species and habitats, recreation and tourism. (3) investigate beach nourishment to ameliorate erosion along the southern developed part of the Bay, where the majority of high risk facilities are located.
\end{abstract}

Keywords: Sedimentary processes, coastal erosion, coastal habitats, regional sediment management, beach nourishment, sand mining

\section{Introduction}

For recreational, economic, and ecological reasons, the sandy beaches and coastal dunes of southern Monterey Bay are among the coastal region's most prized natural resources. Due to a persistent rise in sea level, reductions in sand availability, and public and private development practices, the southern Monterey Bay shoreline south of the Salinas River is eroding, on average, at the fastest rate in California (Hapke et al., 2006). This erosion compromises the

\footnotetext{
${ }^{1}$ Current address: Royal Haskoning, Rightwell House, Bretton, Peterborough, PE3 8DW, UK
} 
ability of the beaches and dunes to buffer oceanfront development and infrastructure from storms and flooding, provide vital natural habitat, and successfully accommodate recreation and tourism.

Along the California coast, state, federal, and local agencies have adopted a new paradigm to address coastal erosion problems caused by human modification. Recognizing that much of California's coastal sediment supply and demand issues can be attributed to changes affecting natural processes at regional scales, the Coastal Sediment Management Workgroup (CSMW), a collaborative workgroup of state, federal and local agencies and other stakeholders involved in sediment management, is pursuing Regional Sediment Management (RSM) throughout coastal California. RSM involves the beneficial reuse of non-contaminated sediment whenever feasible and appropriate, to restore or augment natural processes, and utilizes the littoral cell as the basic planning unit (CSMW, 2006). This paper describes findings from the Coastal RSM Plan developed by CSMW and its partners to address erosion within the southern Monterey Bay littoral cell, between the Salinas River mouth to the north and Point Piños at the southern boundary (Figure 1).

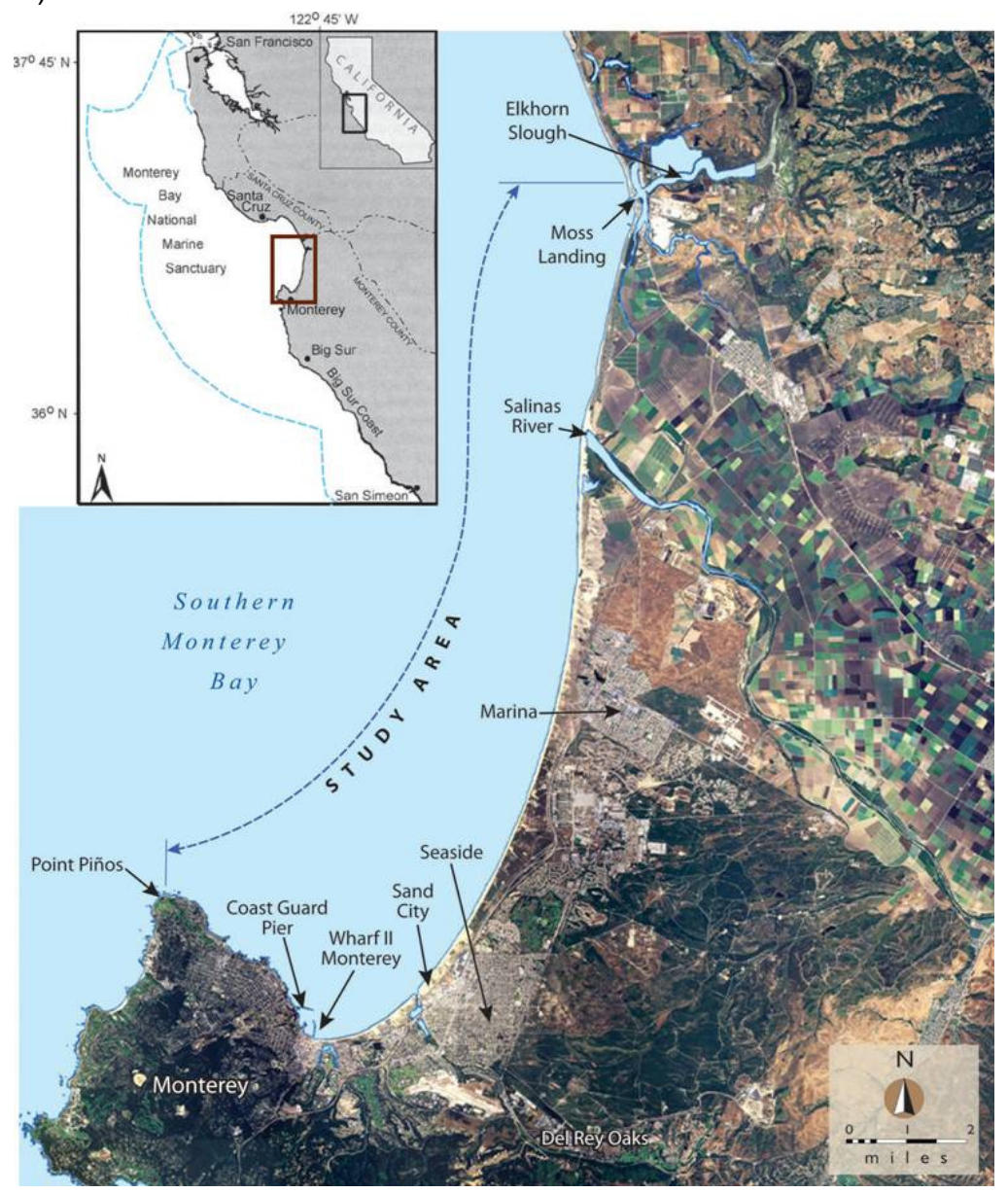

Fig. 1. Location map of southern Monterey Bay showing main developed areas 


\section{Environmental Setting}

The shoreline between the Salinas River mouth and the Wharf II breakwater of Monterey Harbor is composed of sandy beaches backed by relict sand dunes up to several miles wide and 150 feet high (Griggs and Patsch, 2005). Areas landward of the relict dunes are dominated by reclaimed lowlands, and seaward the beaches are bounded by a continental shelf which descends into Monterey Submarine Canyon. Apart from short lengths of riprap and seawall at Sand City and Monterey, the majority (over 96\% by length) of the southern Monterey Bay shoreline is unarmoured (Stamski, 2005). The shoreline north of the Salinas River to Moss Landing is occupied by low relief active dunes backing sandy beaches, which are stable or accreting (Hapke et al., 2006).

\subsection{Wave Climate and Beach Particle Size}

The nearshore wave climate of southern Monterey Bay is dominated by waves from the northwest (Storlazzi and Wingfield, 2005). Refraction occurs as the waves pass over Monterey Submarine Canyon focusing wave energy at Marina and Fort Ord and defocusing energy at Moss Landing. In addition, the shoreline between Monterey and Sand City is sheltered by Point Piños headland from waves from the south and west, resulting in reduced wave energy. The net effect is a large alongshore energy gradient with relatively small wave heights at Monterey increasing to relatively large wave heights at Fort Ord and Marina (Thornton et al., 2007).

The particle size of the beaches between Marina and Wharf II is positively correlated with wave height (Thornton et al., 2007). The smallest mean particle size of approximately $0.2 \mathrm{~mm}$ (fine sand) occurs near Monterey Harbor. The mean particle size then increases northwards to a maximum of approximately $0.7 \mathrm{~mm}$ (coarse sand) at Fort Ord and Marina, followed by a small decrease to $0.6 \mathrm{~mm}$ (coarse sand) further north towards the Salinas River mouth.

\subsection{Sand Transport and the Littoral Cell}

The southern Monterey Bay littoral cell can be divided into three main sub-cells (Figure 2) (Patsch and Griggs, 2007). The boundaries of the sub-cells are defined based on a change in direction of the mean alongshore transport. Wave refraction in Monterey Bay results in a net alongshore sediment divide at the Salinas River, with sand transported north towards Monterey Submarine Canyon and south towards Sand City. A third sub-cell is defined between Point Piños and Monterey Harbor where the alongshore sand transport is to the southeast (Patsch and Griggs, 2007).

It may be possible to further subdivide the central sub-cell at Sand City. Orzech et al. (2010) showed that net sand transport between Sand City and Wharf II (defined as the southern bight) is weakly to the north, owing to a more easterly orientation of the shoreline, resulting in a poorlydefined convergence with the net southerly transport from Fort Ord (Figure 2). At the convergence, which is likely to be seasonally variable in location, sand may migrate offshore. Reid et al. (2006) mapped a lobe of medium-grained sand extending offshore in the vicinity of the convergence zone. 


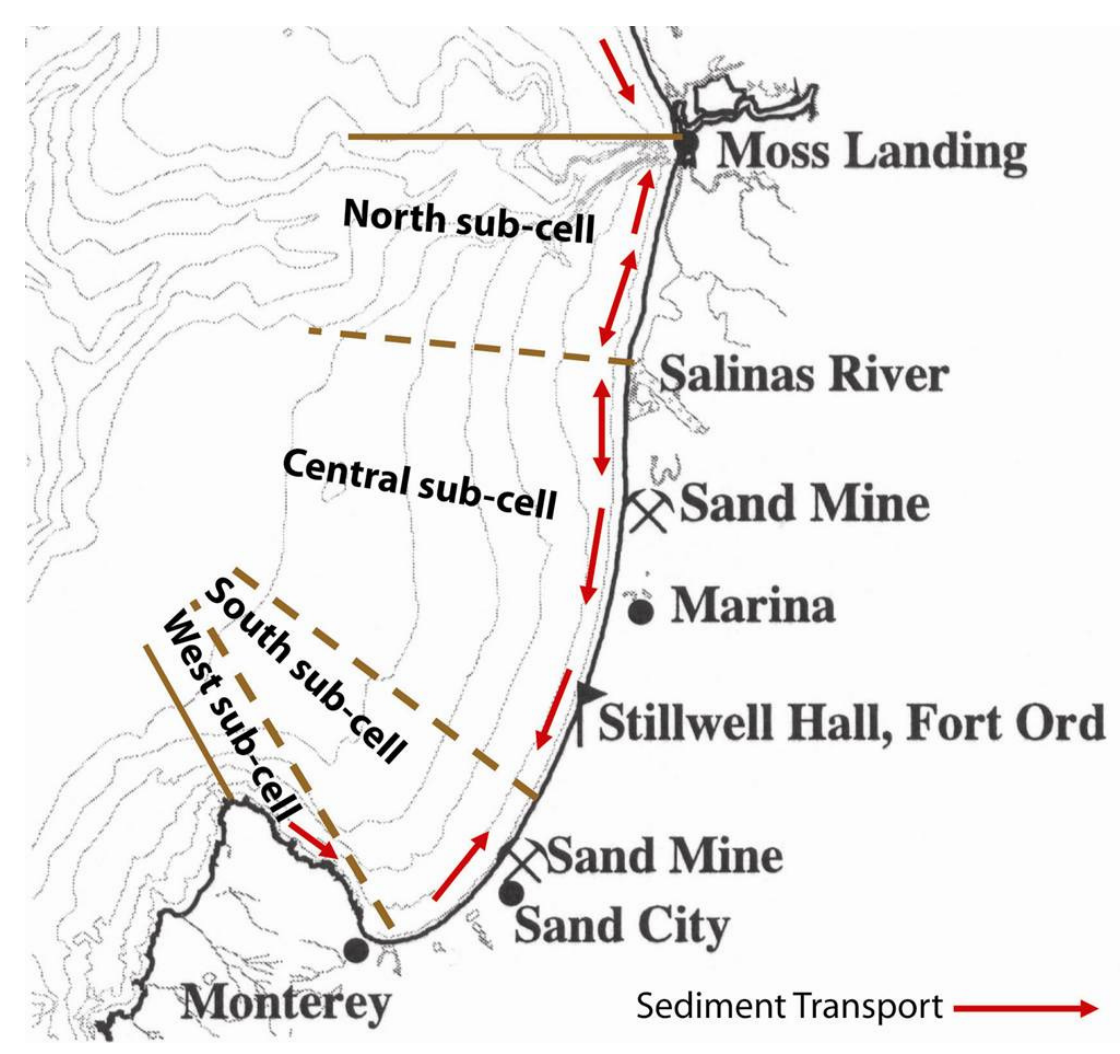

Fig. 2. Southern Monterey Bay littoral sub cells and net sediment transport

\subsection{Sediment Supply to the Littoral Cell}

The largest input of sand to the southern Monterey Bay littoral cell is from erosion of the relict coastal dunes south of the Salinas River. Dune erosion rates between 1985 and 2005 of 0.4 and $4.7 \mathrm{ft} /$ year were measured by Thornton et al. (2006), equating to an average sand yield of approximately $200,000 \mathrm{yd}^{3} /$ year to the littoral cell. Sand supplied to Monterey Bay from the Salinas River is approximately 65,000 yd ${ }^{3} /$ year (McGrath, 1987). CSMW and AMBAG (2008) estimated that only around $10,000 \mathrm{yd}^{3} /$ year (average annual net) of this sand is transported south into the littoral cell, leaving approximately 55,000 $\mathrm{yd}^{3} /$ year of sand transported north towards Monterey Submarine Canyon.

\subsection{Mining of Sand from the Beach}

Southern Monterey Bay has been the most intensively mined shoreline in the United States. Sand mining near the mouth of the Salinas River started in 1906, and expanded to six commercial sites; three at Marina and three at Sand City (Figure 3). Five of these operations used drag lines to mine coarse sand from the surf/swash zone. The sixth mine is located at Marina approximately two miles south of the Salinas River mouth, where the sand is hydraulically extracted just landward of the beach berm by a dredge floating on a self-made pond. Although all drag line sand mines were closed by 1990, the hydraulic Marina operation, 
which began in 1965, is ongoing today. The beach-sand mining operation at Marina efficiently takes advantage of the cross-shore sorting of sediment, where coarse sand is washed over the berm to fill the pond during times of high winter waves and high tide. The pond is repeatedly filled with sand over time and this sand is continuously dredged and removed from the system. CSMW and AMBAG (2008) estimated that approximately 200,000 $\mathrm{yd}^{3} / \mathrm{year}$ of sand has been

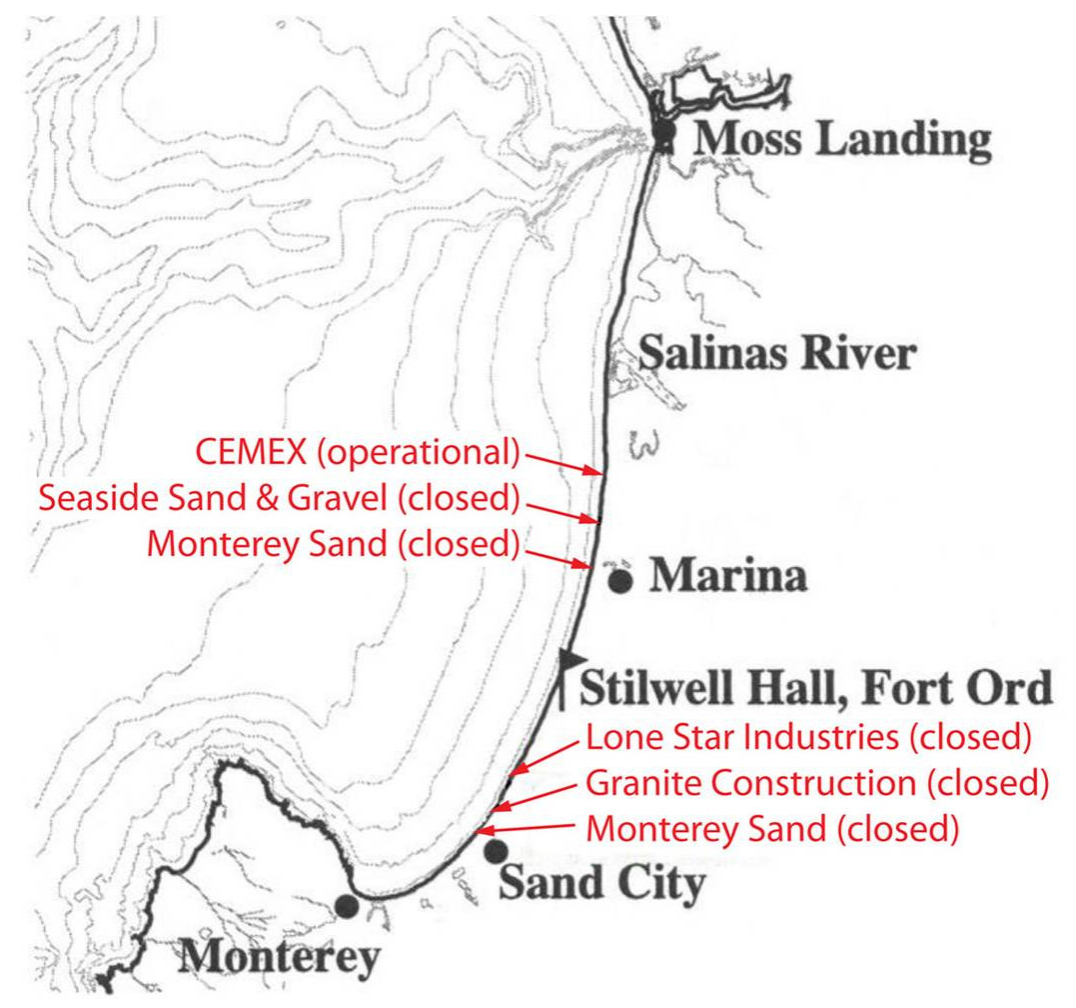
mined from the beach at Marina over the most recent decades.

Fig. 3. Location of former and operating beach-sand mines in southern Monterey Bay

\subsection{Shoreline Habitats}

One of the most important functions of the southern Monterey Bay beach, shoreface, and dune system is its role as habitat for a unique flora and fauna. The dunes represent one of the most important coastal dune ecosystems in California. Numerous native dune plants are either already listed or are on the candidate list for the federal register of endangered and threatened species. The beaches of southern Monterey Bay are home to numerous invertebrate species, which reach high abundance and biomass providing crucial food/prey sources for shorebirds and seabirds. Sensitive nearshore subtidal habitats include rocky reefs, kelp forests, and eelgrass beds (Figure 4), which provide important habitat for fish, invertebrates, and marine mammals. A rocky reef of shale is situated offshore of Del Monte Beach, approximately 600 feet from the beach in up to 230 feet of water. A kelp forest grows on the nearshore portion of the 
reef. To the west of the Del Monte kelp forest is an eelgrass meadow, which once covered 0.1 square miles of the sea bed in water depths of 20-30 feet.

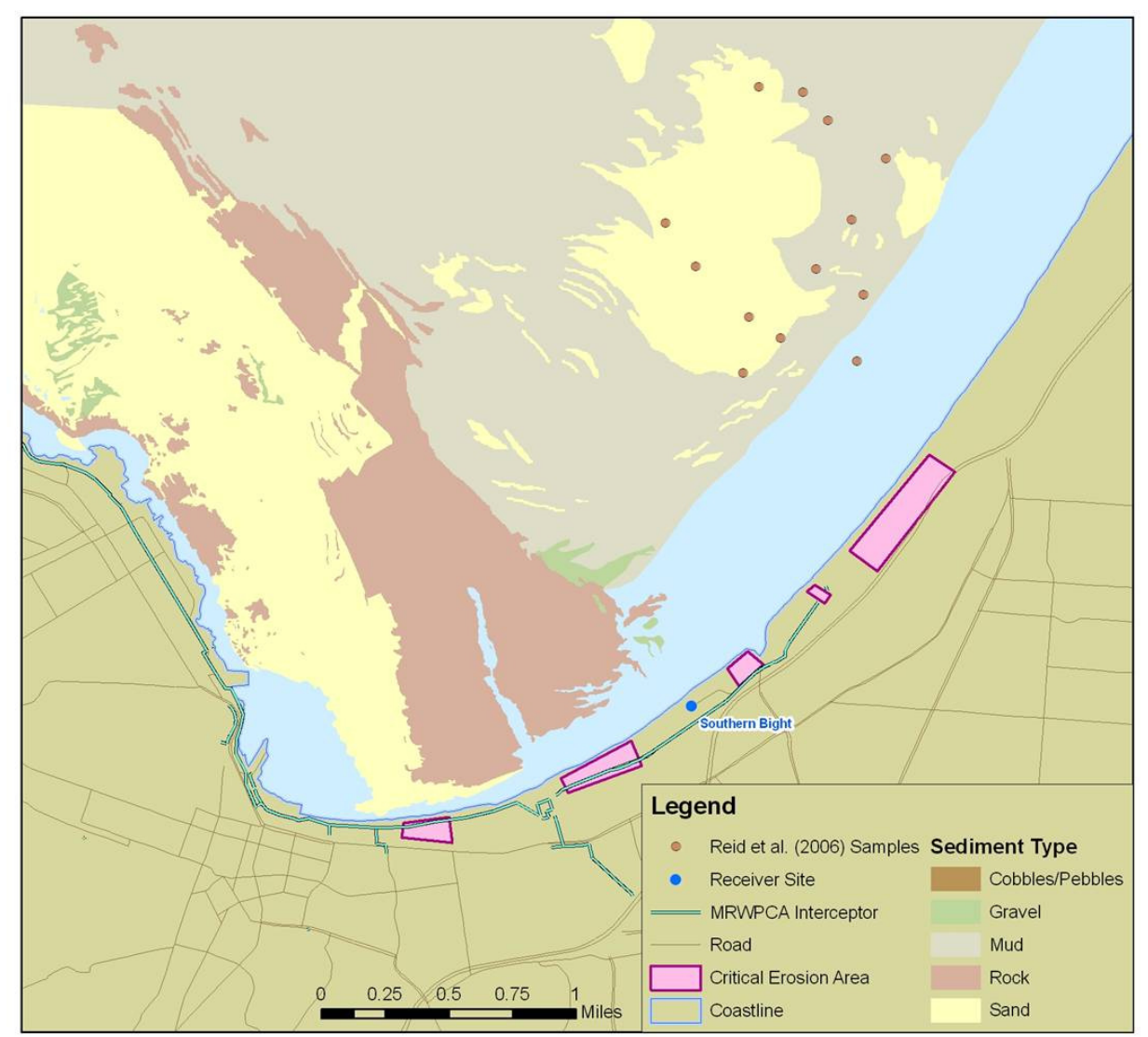

Fig. 4. Locations of sensitive subtidal habitat, critical areas of erosion, and a potential offshore source of sand for beach nourishment

\section{Critical Areas of Erosion}

In order to delineate critical areas of erosion within the southern Monterey Bay littoral cell, two criteria were adopted in the Coastal RSM Plan to prioritize erosion responses over a planning horizon of 50 years; risk of erosion and consequences of erosion. The risk of erosion over a 50year period is based on the risk analysis developed by PWA and Griggs (2004). Three risk categories were defined in the Coastal RSM Plan (CSMW and AMBAG, 2008):

1. Low risk areas are those with a low probability of being impacted by erosion over the next 50 years. 
2. Moderate risk areas are not likely to be affected by chronic erosion over the next 50 years, but are potentially susceptible to short-term storm event erosion within the planning horizon.

3. High risk areas are those that will be located seaward of the shoreline position anticipated in 50 years or presently vulnerable to short-term event-based erosion.

PWA and Griggs (2004) defined the level of risk by assuming that long-term historic erosion rates would continue over the next 50 years. For the definition of critical areas of erosion in the Coastal RSM Plan, the historic erosion rates of Thornton et al. (2006) were used with an increment of approximately $20 \%$ added to the erosion rate for potential increases due to future sea-level rise (CSMW and AMBAG, 2008).

All the areas identified at high or moderate risk of erosion were assessed as to the consequences of their loss. Three consequence categories were defined; high consequence, moderate consequence, and low consequence, based on an evaluation of their economic (potential loss of infrastructure), ecological (potential loss of habitat), and human health and safety (potential loss of life) value. The majority of sites at high to moderate risk of erosion with high consequences of loss are associated with infrastructure located close to the shoreline (Figure 4).

\subsection{Monterey Interceptor and Pump Stations}

The Monterey Interceptor pipeline which carries raw (untreated) wastewater between Seaside and Wharf II is buried beneath the beach or in the dunes, passing through pump stations at Monterey and Seaside. The pipeline and its pump stations are vital facilities that need to remain fully operational indefinitely, and the consequences of their erosion would be significant economic, environmental, and human health impacts. Between Wharf II and the Monterey Pump Station the pipeline lies beneath the beach, and over the next 50 years is under threat from exposure due to beach lowering as the shoreline profile migrates landward. The Monterey Interceptor between Monterey Beach Resort and Seaside Pump Station is buried in the dunes, approximately 100 to 175 feet from the dune bluff. Based on approximate future erosion rates of between 1.5 and $3.0 \mathrm{ft} /$ year, the shoreline would be expected to erode 75-150 feet over the next 50 years, and parts of the pipeline may be compromised over the next 40 years. Seaside Pump Station is located approximately 100 feet from the edge of the low-lying dunes that front the facility. The future rate of erosion is estimated at approximately $3.0 \mathrm{ft} / \mathrm{year}$, and the facility could be compromised by erosion in about 30 years.

\subsection{Marina}

The Sanctuary Beach Resort is located on the dune top at Marina (Figure 1) and under threat over the next 50 years through continued erosion of the dune bluff: The seaward-facing wall and buildings of the complex are set back approximately 120 feet from the top of the bluff. The bluff is estimated to erode at approximately $5.5 \mathrm{ft} /$ year over the next 50 years, meaning that the resort would be compromised in approximately 20 years time. The loss of this facility would have high economic consequences to the region as it is a popular tourist destination. 


\subsection{Southern Bight}

In addition to the Monterey Interceptor and Seaside Pump Station, the southern bight contains several other critical areas of erosion. These include oceanfront properties, which are currently protected from erosion by coastal armoring. Ocean Harbor House condominiums are located on the dunes behind Del Monte Beach in Monterey. Since the condominiums were completed in 1969, a history of erosion problems resulted in a series of emergency revetments that have recently been replaced by a massive seawall. The seawall fixes the shoreline while the dunes to either side continue to erode. The condominiums are privately owned and the consequences of their loss would be economically damaging and hazardous to safety.

The Monterey Beach Resort hotel is located on north Del Monte Beach, surrounded by a seawall. Since it was built in 1968, shoreline erosion has occurred up and down coast, and the protected hotel has become a headland. The presence of the seawall has led to beach erosion to the extent that during high tides there is now no public access in front of the hotel. The future erosion rate at north Del Monte Beach is estimated to be approximately $1.5 \mathrm{ft} /$ year. The hotel continues to be a popular tourist destination and loss of this facility would have high economic consequences.

\section{Regional Sediment Management Approaches}

Three regional sediment management approaches are recommended in the Coastal RSM Plan as potential solutions to the coastal erosion problems in southern Monterey Bay (CSMW and AMBAG (2008) (Figure 5). These are 1) reduce or eliminate large-scale removal of sand from the beach through mining at Marina; 2) allow the natural processes of dune erosion to continue without intervention north of Sand City; and 3) beach nourishment in the southern bight to slow erosion rates.

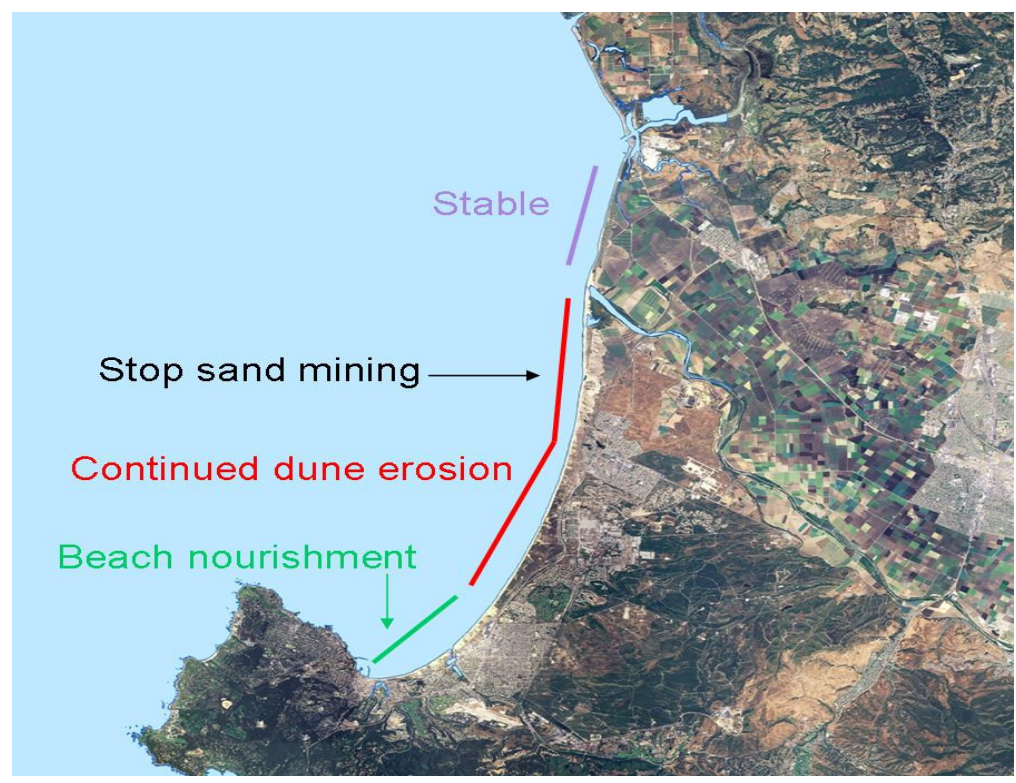

Fig. 5. Potential regional sediment management approaches in southern Monterey Bay 


\subsection{Reduce or Eliminate Removal of Sand from the Beach at Marina}

The main human factor that affects the sediment budget of the southern Monterey Bay littoral cell is sand mining from the beach at Marina. Historically, the mining of sand from the beach has disrupted alongshore sand transport, and ultimately resulted in enhanced beach erosion. Cessation of mining sand from the beach at Marina would allow approximately 200,000 $\mathrm{yd}^{3} /$ year of sand to remain in the littoral system. Gross alongshore sand transport is sufficiently high in southern Monterey Bay to distribute the sediment demand caused by mining throughout the littoral cell, and especially to the south. Cessation of mining would reduce erosion rates by about half, and would provide more sand to buffer future erosion, increase beach widths, reduce threat of damages to property and infrastructure, and enhance beach habitat.

Erosion is particularly acute at the Sanctuary Beach Resort critical area of erosion (Figure 1). This resort is located approximately one mile south of the sand mine and the erosion rates of the dunes on which it is located are directly affected by the extraction of sand from the beach. Replenishment of the beach in front of the Sanctuary Beach Resort with sand that would otherwise be removed from the system would provide a larger and more effective buffer to waves, reducing the dune erosion rates. The Coastal RSM Plan recommends cessation of mining of sand from the beach because of its impact on regional rates of shoreline erosion. Details of potential strategies to implement this recommendation, including both regulatory and non-regulatory possibilities, are described in the Plan (CSMW and AMBAG, 2008).

\subsection{Allow Dune Erosion to Continue}

As the coastal dunes are the primary source of sand to the beaches, the 'no action' approach would allow the natural processes of dune erosion to continue without human intervention. In the portion of the littoral cell from the City of Sand City to the Salinas River (approximately 13 miles), erosion of the dunes is providing large quantities of sand to the littoral system, helping to maintain the beaches and affording benefits for sensitive species and habitats. The dunes are sufficiently wide and high so there is no threat of flooding to the low-lying areas behind them. This region is not a good candidate for beach nourishment owing to the high wave energy, highly erosive nature of the beach with large particle size, and a relatively high rate of sediment transport. The Coastal RSM Plan recommendation is to allow the dunes between the Salinas River and the northern boundary of the City of Sand City to continue to erode (CSMW and AMBAG, 2008).

\subsection{Beach Nourishment}

At locations where it is not desirable to allow natural erosion processes to continue, due to the beach resource being lost and/or important facilities are at high risk and consequences of erosion, the Coastal RSM Plan recommends beach nourishment to modify the shoreline. The Southern Monterey Bay Coastal Erosion Workgroup, a taskforce of local, state and federal agencies, NGOs and other interested stakeholders, proposed analysis of the feasibility of beach nourishment to ameliorate erosion along the southern bight, and the Coastal RSM Plan generally supports that proposition (CSMW and AMBAG, 2008), assuming that environmental 
concerns can be addressed. Numerous critical areas of erosion are located along the southern bight (Figure 3) and healthy beaches are especially important for recreation and tourism.

Beach nourishment appears to be geomorphologically feasible in the southern bight for a number of reasons. Relatively lower wave energy and sand transport, and occupation of a potential sub-cell (the southern bight could be self-contained in terms of net sand transport, Figure 1) means that any placed sand would remain in this coastal segment for a longer period of time. Beach nourishment would also reduce the need for 'hard' shore protection, and would provide positive ecological benefits associated with wider beaches over the longer term. Sand would need to be placed at a location away from the rocky reef, kelp forest and eelgrass meadow to avoid disturbance due to suspension and turbidity, and be allowed to spread along the shoreline.

The Coastal RSM Plan targets two substantive sources of sand for beach nourishment where the sediment is a similar particle size (or larger) to the beaches of the southern bight (CSMW and AMBAG, 2008); sand offshore from Sand City, and Monterey Submarine Canyon. A large body of medium-grained sand is located offshore from Sand City (Reid et al., 2006). The mean particle size of this offshore sand $(0.25-0.5 \mathrm{~mm})$ is compatible with the beach sands of the southern bight and it is a potential large source of sand for beach nourishment. In addition, the head of Monterey Submarine Canyon, marking the northern boundary of the southern Monterey Bay littoral cell (Figure 1), is effective at capturing littoral sediments that are diverted offshore by Moss Landing harbor jetties (Smith et al., 2007). This sand could be recovered before being lost down the canyon and used for nourishment. However, the canyon is some distance away and therefore may not be as economically attractive as the sand deposit offshore of Sand City.

\section{Conclusions}

Over the next 50 years, the coastal dunes of southern Monterey Bay are predicted to erode at rates between approximately 1.0 and $6.0 \mathrm{ft} /$ year. Over this planning time frame, numerous oceanfront facilities are at high risk due to this erosion, and will require implementation of mitigation measures to prevent loss. The beaches and dunes of southern Monterey Bay also provide important habitat for native animals and numerous shorebirds. Sensitive subtidal habitats, including rocky reef, kelp forest, and eelgrass meadow are located adjacent to the Monterey shoreline.

The dominant supply of sand to the littoral cell is produced from erosion of the coastal dunes south of the Salinas River. Current dune erosion rates range from approximately 0.5 to 5.0 $\mathrm{ft} /$ year, equating to a sand volume of approximately $200,000 \mathrm{yd}^{3} /$ year supplied to the littoral system. The most significant sink for sand is the ongoing beach-sand mining operation at Marina, which currently permanently extracts $200,000 \mathrm{yd}^{3} /$ year from the beach, similar to the annual sand volume yielded by the dunes.

The Coastal RSM Plan for southern Monterey Bay (CSMW and AMBAG, 2008) examined regional sediment management options that restore coastal habitat by removing or lessening disturbances to natural sedimentary processes that exacerbate coastal erosion. The Coastal 
RSM Plan recommends implementing three regional sediment management strategies for the southern Monterey Bay shoreline:

1. Reduce or eliminate mining of sand from the beach at Marina. If this sand is available and subsequently transported alongshore, it could provide a significant additional buffer to dune erosion by waves. The effect would be more immediate close-by, but would eventually benefit the shoreline further afield.

2. Allow dune erosion to continue without human intervention from the City of Sand City to the Salinas River. This erosion will continue to supply large quantities of sand to the beaches, helping to maintain their healthy condition and provide benefits for sensitive species and habitats, recreation and tourism.

3. Investigate beach nourishment to ameliorate erosion in the southern bight, which includes the cities of Monterey, Seaside, and Sand City. The majority of high risk facilities are located within this stretch of shoreline, and healthy beaches therein are particularly important for recreation and tourism.

\section{References}

CSMW (California Coastal Sediment Management Workgroup), 2006. California Coastal Sediment Master Plan Status Report, September 2006.

CSMW (California Coastal Sediment Management Workgroup) and AMBAG (Association of Monterey Bay Area Governments), 2008. Coastal Regional Sediment Management Plan for Southern Monterey Bay.

Griggs, G. and Patsch, K., 2005. Ano Nuevo to the Monterey Peninsula. In: Griggs, G., Patsch, K. and Savoy, L. Living with the Changing California Coast. University of California Press, 270310.

Hapke, C.J., Reid, D., Richmond, B.M., Ruggiero, P. and List, J., 2006. National Assessment of Shoreline Change Part 3: Historical Shoreline Change and Associated Coastal Land Loss along Sandy Shorelines of the California Coast. U.S. Geological Survey Open-File Report 2006-1219, $72 \mathrm{p}$.

McGrath, J., 1987. Sand mining and erosion in Monterey Bay. Proceedings of Coastal Zone '87, v5. (Seattle, Washington), pp. 5786-5811.

Orzech, M.D., Thornton, E.B., MacMahan, J.H., O'Reilly, W.C. and Stanton, T.P., 2010. Alongshore rip migration and sediment transport in southern Monterey Bay. Journal of Geophysical Research.

Patsch, K. and Griggs, G., 2007. Development of Sand Budgets for California's Major Littoral Cells. Eureka, Santa Cruz, Southern Monterey Bay, Santa Barbara, Santa Monica (including Zuma), San Pedro, Laguna, Oceanside, Mission Bay, and Silver Strand littoral cells. Institute of Marine Sciences, University of California, Santa Cruz, 115p. 
PWA (Philip Williams and Associates) and Griggs, G., 2004. Southern Monterey Bay Coastal Erosion Services. Monterey Regional Water Pollution Control Agency.

Reid, J.A., Reid, J.M., Jenkins, C.J., Zimmermann, M., Williams, S.J. and Field, M.E., 2006. usSEABED: Pacific Coast (California, Oregon, Washington) offshore surficial-sediment data release: U.S. Geological Survey Data Series 182, version 1.0.

Smith, D.P., Kvitek, R., lampietro, P.J. and Wong, K., 2007. Twenty-one months of geomorphic change in upper Monterey Canyon (2002-2005), Marine Geology, 236, 79-94.

Stamski, R., 2005. Coastal erosion and armoring in southern Monterey Bay. A technical report in support of the Monterey Bay National Marine Sanctuary Coastal Armoring Action Plan. Version 1.1, June 2005, 68pp.

Storlazzi, C.D. and Wingfield, D.K., 2005. Spatial and temporal variations in oceanographic and meteorologic forcing along the central California coast, 1980-2002. U.S. Geological Survey Scientific Investigations Report 2005-5085.

Thornton, E.B., Sallenger, A., Conforto Sesto, J., Egley, L., McGee, T. and Parsons, R., 2006. Sand mining impacts on long-term dune erosion in southern Monterey Bay. Marine Geology, 229, 45-58.

Thornton, E.B., MacMahan, J. and Sallenger, A.H., 2007. Rip currents, mega-cusps, and eroding dunes. Marine Geology, 240, 151-167.

\section{Acknowledgements}

We are grateful for funding provided to the Association of Monterey Bay Area Governments by the California Department of Boating and Waterways on behalf of the California Coastal Sediment Management Workgroup's (CSMW's) efforts to implement their Coastal Sediment Master Plan. The Coastal RSM Plan was developed in close collaboration with the Southern Monterey Bay Coastal Erosion Workgroup, and supplements their ongoing efforts to address the issues of shoreline erosion and armoring in southern Monterey Bay and develop a regional planning approach. We also acknowledge the U.S. National Oceanographic and Atmospheric Administration (NOAA) and Monterey Bay National Marine Sanctuary for their participation and leadership of the Workgroup. 